\title{
PENGARUH SUKU BUNGA LUAR NEGERI FEDERAL RESERVE (THE FED), NILAI TUKAR RUPIAH/US \$ DAN INFLASI TERHADAP INDEKS HARGA SAHAM GABUNGAN DI BURSA EFEK INDONESIA PERIODE 2006-2008
}

\author{
Oleh: \\ Misgiyanti \\ Alumni Fakultas Ekonomi Universitas Muhammadiyah Malang \\ Idah Zuhroh \\ Fakultas Ekonomi Universitas Muhammadiyah Malang \\ E-mail/No. Hp: - /0341460021
}

\begin{abstract}
The hypothesis are guess that Fed Rate negative influence to jakarta stock composite index, guess that foreign exchange negative influence to jakarta stock composite index and inflation negative influence to jakarta stock composite index. Analysis instrument to knowing influence of fed rate, foreign exchange and inflation are use multiple linier regression analysis. To know what is the reach of independent variable influence to dependent variable use a hypothesis testing with a partial test ( $t$ test), simultant test ( $f$ test) and to knowing how the independent variable representative to dependent variable use a godness of fit $\left(R^{2}\right)$. The results of hypothesis analysis shows that Fed rate, foreign exchange and inflation have a simultant significant influence to jakarta stock composite index. The evidence from the results shows that $F$ test $>F$ table $(35,51624>2,95)$. Partial test shows that Fed rate has negative influence to jakarta stock composite index which $t$ test > t table ((-6.016280 >2,048), foreign exchange has not influence to jakarta stock composite index with level a significant $5 \%$ and inflation has negative influence to jakarta stock composite index.
\end{abstract}

Keywords : FED rate, foreign exchange, inflation

\section{PENDAHULUAN}

The Fed yang merupakan bank sentral di Amerika Serikat bertanggung jawab memantau dan menanggapi perkembangan perekonomian secara keseluruhan, dan pasar saham adalah bagian dari perekonomian. The Fed (Federal Reserve) mengawasi pasar saham dan dapat mempengaruhi suku bunga dan aktivitas ekonomi bagi Indonesia. Saat ini hampir semua pasar saham termasuk di kawasan regional, mengamati dengan cermat perkembangan saham di Amerika
Serikat. Apa yang dikatakan Fed akan sangat diikuti pasar. Pasar akan bereaksi cepat menyangkut rencana kebijakan The Fed.

The Fed pada bulan April menurunkan suku bunga sebesar 25 basis poin yang akan berdampak positif pada penguatan Indeks Harga Saham Gabungan (IHSG) Bursa Efek Indonesia (BEI). Perkiraan penurunan sebesar 25 basis poin suku bunga The Fed dari 2,25 menjadi 2,00 bisa menjadi sentimen positif indeks regional. Sehingga hal ini mengakibatkan banyaknya aliran dana 
yang keluar dari Negara Amerika dan masuk ke Indonesia.

Mengalirnya dana dari luar negeri tersebut diharapkan dapat menaikkan nilai tukar rupiah terhadap dollar AS. Sebagaimana yang diungkapkan Mentri koordinator Perekonomian di Jakarta (2008), menilai bahwa reboundnya rupiah sebagai wujud respons positif pasar atas diturunkannya suku bunga pinjaman The Fed (discount rate).

Badan Pusat Statistik (BPS) mencatat angka inflasi pada bulan Maret 2008 sebesar $0.95 \%$. Angka ini berarti lebih lebih tinggi dari angka inflasi bulan Februari yang sebesar $0.65 \%$ (MoM). Pemicu tingginya inflasi berasal dari kelompok bahan makanan yang naik sebesar $1.44 \%$, kelompok makanan jadi, minuman, rokok dan tembakau sebesar $1.08 \%$; dan kelompok sandang yang naik sebesar $1.17 \%$. Berdasarkan angka inflasi bulanan tersebut maka angka inflasi tahun kalender (YtD) tercatat sebesar $3.14 \%$, sedangkan laju inflasi tahunan $(Y o Y)$ tercatat sebesar $8.17 \%$. Inflasi bulan juli ini sebesar $11,90 \%$ $(M o M)$.

Tetap tingginya tekanan inflasi dan kenaikan harga-harga komoditas pada tahun 2008 akan tetap menjadi ancaman dan menjadi sentimen negatif bagi pasar modal di Indonesia yang dapat menyebabkan tingginya volatilitas harga-harga saham di Bursa Efek Indonesia. Dari sisi positifnya, hal ini dapat dilihat sebagai peluang untuk mengakumulasi saham-saham yang memiliki kinerja fundamental yang baik pada harga murah.

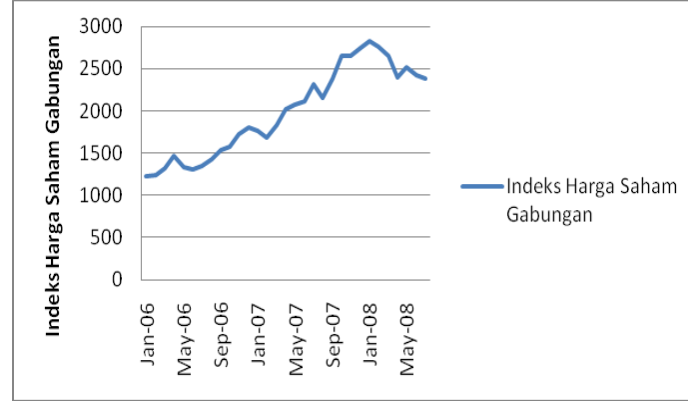

Gambar 1. IHSG Periode Januari 2006Juli 2008

Naik turunnya Indeks Harga Saham Gabungan merupakan indikator naik turunnya harga saham yang tercatat di bursa baik itu saham biasa maupun saham preferen. Sehingga nilai Indeks Harga Saham Gabungan bisa digunakan sebagai gambaran tentang kondisi keadaan yang terjadi di pasar modal, maksudnya adalah jika nilai indeks harga saham yang terjadi di bursa efek akan mengalami penurunan maka dapat dipastikan sebagian harga saham yang terjadi di bursa efek akan mengalami penurunan. Sebagai salah satu indikator utama pasar modal indeks harga saham gabungan sangat penting bagi bagi para investor baik itu dari dalam negeri maupun luar negeri, dalam hal ini nilai indeks harga saham gabungan digunakan sebagai pertimbangan dalam menilai kinerja pasar modal yang ada, baik yang berkaitan dengan likuiditas maupun untuk tingkat pengembalian investasi (return of investment).

Masalah kurs tukar sangat berpengaruh terhadap pasar modal. Fluktuasi mata uang dalam negeri terhadap mata uang asing akan tercermin dalam index harga saham. Indonesia saat ini menggunakan kurs mengambang dengan nilai kurs tukar yang bebas stabil. Apresiasi dan depresiasi nilai tukar Rupiah dapat mengakibatkan naik atau turunnya harga saham. Hal ini disebabkan oleh kebijakan emiten dari saham apakah mengekspor bahan baku ataupun barang jadi ke dalam atau ke 
luar negeri. Apabila perusahaan akan mengimpor bahan baku dari luar negeri ketika Rupiah mengalami apresiasi maka biaya maka biaya produksi akan dapat ditekan sehingga profit perusahaan akan naik yang pada akhirnya akan meningkatkan harga saham perusahaan. Berdasarkan latar belakang diatas dapat merumuskan permasalahan 1) Apakah tingkat suku bunga The Fed, nilai tukar Rupiah/US\$, Inflasi mempengaruhi IHSG di BEI? 2) Seberapa besar tingkat suku bunga The Fed, nilai tukar Rupiah/US\$, Inflasi mempengaruhi IHSG di BEI?

\section{TINJAUAN PUSTAKA}

Menurut Mankiw (2002:176), The Fed badan keuangan yang bertanggung jawab dalam mengatur perbankan dan mengatur jumlah uang beredar dalam perekonomian adalah Federal Reserve (Bank Sentral AS) yang sering disingkat dengan The Fed. The Fed merupakan salah satu Bank sentral yaitu institusi yang dirancang untuk mengawasi sistem perbankan dan mengatur jumlah uang yang beredar dalam perekonomian. The Fed didirikan pda tahun 1914 setelah serangkaian kegagalan bank pada tahun 1907 meyakinkan kongres bahwa AS membutuhkan sebuan institusi untuk menjaga kesehatan sistem perbankan nasional.

The Fed memiliki dua tugas yang saling berkaitan yaitu 1) Mengatur bankbank dan menjaga kesehatan sistem perbankan; The Fed memonitor kondisi keuangan masing-masing bank dan memfasilitasi transaksi-transaksi bank dengan melakukan kliring. The Fed juga memberikan pinjaman kepada bank yang ingin melakukan pinjaman. Ketika bankbank mengalami masalah finansial, the Fed bertindak sebagai pemberi pinjaman terakhir (pemberi pinjaman kepada mereka yang tidak lagi dapat menemukan tempat meminjam uang), dengan tujuan mempertahankan stabilitas keseluruhan sistem perbankan; 2) Mengendalikan jumlah uang yang beredar dalam perekonomian. Keputusan-keputusan yang diambil terfokus pada jumlah uang yang beredar yang disebut dengan kebijakan moneter. Kebijakan moneter dibuat oleh Komite Pasar Terbuka Federal (Federal open Market Comunity-FOMC). FOMC melakukan pertemuan setiap enam minggu sekali di Washington DC, untuk membahas kondisi ekonomi dan perubahan-perubahan dalam kebijakan moneter.

Menurut Mankiw (2004:336) The Fed bertanggung jawab untuk memantau dan menanggapi perkembangan perekonomian secara keseluruhan, dan pasar saham merupakan bagian dari perekonomian. Ketika pasar saham mengalami kenaikan, rumah tangga menjadi lebih kaya, dan peningkatan kekayaan ini memdorong pembelanjaan konsumen. Selain itu, kenaikan harga saham juga membuat perusahaan lebih tertarik untuk menjual saham baru, dan hal ini mendorong pengeluaran investasi. Untuk kedua alasan tersebut, bullish di pasar saham dapat meningkatkan permintaan agregat barang dan jasa.

Salah satu tujuan The Fed adalah menstabilkan permintaan agregat, karena permintaan agregat yang semakin stabil berarti output dan tingkat harga juga semakin stabil. karena dua alasan. Untuk melakukan hal tersebut, The Fed menanggapi bullishnya harga saham dengan mempertahankan jumlah uang yang beredar tetap lebih rendah dan suku bunga lebih tinggi.

Namun sebaliknya ketika pasar saham mengalami kelesuan. Pengeluaran untuk konsumsi dan investasi menurun, sehingga menekan permintaan agregat dan mendorong perekonomian ke arah resesi. Untuk menstabilkan permintaan agregat, The Fed harus meningkatkan 
jumlah uang yang beredar dan menurunkan tingkat suku bunga.

Sementara The Fed mengawasi pasar saham, partisipan pasar saham juga mengawasi The Fed, karena The Fed dapat mempengaruhi suku bunga dan aktifitas ekonomi, maka Fed juga dapat mempengaruhi nilai saham. ketika The Fed meningkatkan suku bunga maka banyak uang yang terserap sehingga jumlah uang beredar berkurang, hal itu berakibat memiliki saham akan terlihat kurang menarik karena dua alasan:

Pertama Suku bunga yang lebih tinggi berarti tabungan, sebagai alternatif dari saham, akan memberikan pengembalian yang lebih tinggi.

Kedua Pengetatan kebijakan moneter oleh Fed berisiko mendorong perekonomian kearah resesi, yang nantinya akan mengurangi laba. Akibatnya, harga saham sering kali turun ketika Fed meningkatkan suku bunga.

Menurut pengamat ekonomi Fadly Hasan (2008) di Indonesia, ketika The Fed meningkatkan suku bunga maka SBI naik akibatnya terjadi subtitusi antara permintaan di pasar uang dengan pasar modal. Ketika suku bunga bank atau tabungan naik maka investasi beralih dari pasar saham ke pasar uang, sehingga permintaan pasar saham turun akibatnya Indeks Harga Saham Gabungan turun. Ditinjau dari sisi investor. apabila suku bunga The Fed naik akan terjadi dana keluar (capital out flow) maka akan semakin banyak investor yang menjual sahamnya dan beralih ke tabungan yang ada di luar negeri (Amerika) dan Indeks Harga Saham Gabungan turun. Sebaliknya apabila suku bunga The Fed turun akan terjadi dana masuk (capital inflow) maka akan semakin banyak investor luar negeri membeli saham di Indonesia sehingga Indeks Harga Saham Gabungan naik.

Menurut Mandala dan Pratama (2004:74) Nilai tukar adalah harga suatu mata uang dinilai dengan mata uang lain. Pergerakan nilai tukar mencerminkan perubahan tingkat kelangkaan. Suatu mata uang dikatakan semakin naik apabila nilai tukarnya semakin menguat, hal ini mengindikasikan mata uang tersebut semakin langka, Kurs memiliki 2 sifat yaitu a) Volatile, yang artinya kurs peka untuk berubah b) Vis a vis, yang artnya kurs selalu dinyatakan secara berhadapan. Contoh Rp 2.200,per US\$ berarti US\$ / 2.200 per Rupiah.

Sebagaimana layaknya harga, maka kurs juga bisa naik turun dan telah dijelaskan di atas bahwa harga kurs mempunyai sifat volatile. a) Kurs naik disebut Apresiasi jika penyebab kenaikannya adalah kekuatan pasar. b)Kurs turun disebut Depresiasi jika penyebab kenaikannya adalah kekuatan pasar.c)Kurs naik disebut Revaluasi jika penyebab kenaikannya adalah kebijakan pemerintah.d)Kurs turun disebut Devaluasi jika penyebab kenaikannya adalah kebijakan pemerintah.

Ada beberapa teori yang digunakan dalam menganalisis terjadinya keseimbangan kurs antara lain: (Rosyadi;2002)

Pertama, Pendekatan perdagangan (trade oproach) atau pendekatan elastisitas terhadap pembentukan kurs. Menurut teori ini bahwa equilibrium adalah kurs yang akan menyeimbangkan nilai import dan eksport suatu negara. Jika import suatu negara lebih besar dari ekspornya, maka kurs tukarnya akan mengalami peningkatan (mengalami depresiasi). Peningkatan kurs tukar (nominal exchange rate) akan membuat harga dari komoditi ekspornya menjadi lebih murah bagi para importir dan produk barang dan jasa import menjadi lebih mahal bagi penduduk domestik. Akibatnya, lambat laun eksport negara tersebut akan naik sedangkan import akan tertekan, sampai nilai perdagangan internasional benar-benar seimbang. 
Kedua, Teori paritas daya beli (purchasing power parity) Model ini lebih relevan di aplikasikan guna megamati pergerakan kurs dalam jangka panjang ketimbang dalam jangka pendek. Teori ini berdalih bahwa perubahan kurs senantiasa sebanding atau proporsional dengan perubahan rasio tingkat harga umum di kedua negara yang terkait. Berdasarkan hukum satu negara, bahwa komoditi yang sama seharusnya memiliki harga yang sama pula dan prinsip ini harus terjadi di negara manapun apabila dinyatakan dalam satuan mata uang yang sama.

Teori purchasing power parity ada 2 versi pokok yakni versi absolut dan versi relative. Versi absolut menyatakan bahwa kurs sama dengan tingkat harga relatif. Sedangkan versi relative menyatakan bahwa perubahan preosentase dalam kurs antara dua mata uang selama periode tertentu sama dengan selisih antara prosentase perubahan atas tingkatan harga diberbagai negara. purchasing power parity relative juga menerangkan bahwa tingkat harga dan kurs senantiasa mengalami perubahan sehingga rasio daya beli domestik dan luar negeri dari setiap negara tetap bertahan.

Versi absolut menyatakan bahwa kurs equilibrium sama dengan rasio tingkat harga yang berlaku di kedua negara yang terkait. Secara spesifik persamaan model ini adalah: $\mathrm{R} a b=\mathrm{P} a / \mathrm{P} b$ yang mana, Rab adalah kurs antara mata uang negara $\mathrm{A}$ dan mata uang negara $\mathrm{B}$, sedangkan $\mathrm{P} a$ dan $\mathrm{P} b$ masing-masing mengacu pada tingkat harga umum yang berlaku di negara A dan negara B.

Versi absolut merupakan model penyempurnaan versi absolut. Versi ini menyatakan bahwa perubahan kurs dalam jangka waktu tertentu akan bersifat proposional atau sebanding terhadap perubahan tingkat harga yang berlaku di kedua negara selama periode yang sama.

Moneter approach (pendekatan moneter) Ada dua komponen dasar teori kurs moneter (Maurice 2002;153), pertama, menghubungkan tingkat harga di negara yang berbeda terhadap penawaran mata uang negara. Kedua, menghubungkan tingkat harga terhadap kurs.

Pendekatan moneter terhadap kurs juga mengasumsikan bahwa masyarakat menyesuaikan kepemilikan uangnya sampai kuantitas uang yang diminta sama dengan kuantitas uang yang ditawarkan (rasio harga dua negara yang berbeda adalah hubungan erat dengan kurs antar mata uang kedua negara).

Pendekatan moneter ini menyatakan bahwa sesungguhnya kurs di tentukan proses penyeimbangan dan penyamaan tingkat permintaan dan penawaran mata uang nasional di masing-masing negara. Semakin tinggi pendapatan riil dan harga yang berlaku di negara tersebut maka akan semakin besar pula permintaan uang di negara tersebut karena setiap individu dan perusahaan memerlukan lebih banyak uang untuk membiayai transaksi hariannya.

Pendekatan ini memprediksikan bahwa kurs akan mangalami depresiasi sebesar kelebihan pertumbuhan uang disuatu negara terhadap negara lain. Pertumbuhan GNP riil yang lebih cepat akan menyebabkan apresiasi dan tingginya tingkat suku bunga. Inflasi diharapkan akan menyebabkan depresiasi.

Portofolio balance approach (pendekatan keseimbangan portofolio). Pendekatan keseimbangan portofolio mengakui bahwa masyarakat mungkin ingin memegang kedua mata uang, walapun mungkin memiliki preferensi terhadap salah satu mata uang (mata uang negaranya sendiri). Pendekatan ini 
mengasumsikan bahwa mungkin masyarakat di kedua negara lebih suka surat berharga domestik dan asing atau masyarakat lebih suka mendiversikan portofolio sekuritas dari negara yang berbeda (obligasi domestik dan luar negeri sebagai subsitusi yang tidak sempurna).

Apabila nilai kurs valas naik maka indeks harga saham dapat mengalami penurunan. Hal tersebut disebabkan ketika nilai tukar memgalami depresiasi maka nilai mata uang akan turun sehingga mendorong terjadinya inflasi. Ketika produsen melakukan perdagangan bahan produksi dari luar negeri harga akan naik, yang akan menyebabkan perusahaan akan menaikkan harga output produksinya, sedangkan daya beli masyarakat cenderung turun dikarenakan harga sebagai produksi naik, maka perusahaan akan rugi dan sebaliknya.

Menurut Nopirin (94:162) kurs yang berubah-ubah akan menyebabkan ketidakstabilan di dalam lalu lintas pembayaran internasional sehingga dapat mengurangi volume perdagangan Internasional. Terutama pada negara yang sangat tergantung pada perdagangan luar negeri, perubahan kurs akan menyebabkan perubahan hargaharga di dalam negeri. Akibat selanjutnya, kepercayaan masyarakat akan mata uang serta efisiensi alokasi faktor produksi akan turun.

Apresiasi dan depresiasi nilai tukar Rupiah dapat mengakibatkan naik atau turunnya harga saham. Hal ini disebabkan oleh kebijakan emiten dari saham apakah mengekspor bahan baku ataupun barang jadi ke dalam atau ke luar negeri. Apabila perusahaan akan mengimpor bahan baku dari luar negeri ketika Rupiah mengalami apresiasi maka biaya maka biaya produksi akan dapat ditekan sehingga profit perusahaan akan naik yang pada akhirnya akan meningkatkan harga saham perusahaan.

Pengaruh kurs tukar terhadap harga saham menurut Hadi (1997) bisa diklasifikasi menjadi dua kepentingan yaitu pertama, di tinjau dari sisi perusahaan dan kedua, ditinjau dari sisi investor asing.

Perusahaan yang bertransaksi ekspor impor secara otomatis sangat sensitif oleh fluktuasi kurs valas atau foreign exposur misal: jika Rupiah terdepresiasi terhadap Dollar, maka beban impor perusahaan nasional akan semakin meningkat. Berubahnya kurs valas akan mempengaruhi penawaran dan permintaan dalam negara sehingga berpengaruh terhadap cash flow perusahaan.

Pengaruh fluktuasi perusahaan kurs valas terhadap perusahaan secara umum di bedakan menjadi 3 macam: Pertama, Transaksi exposure, Maksudnya resiko pengaruh fluktuasi kurs valas terhadap future cash transaction. Setiap depresi atau rupiah akan mempengaruhi tingkat penerimaan dan pengeluaran perusahaan sehingga akan mempengaruhi keuntungan perusahaan.

Kedua, Economic eksposure. Maksudnya pergerakan kurs valas akan berpengaruh terhadap present value dari future cash flow suatu perusahaan. Setiap perubahan kurs valas akan berpengaruh terhadap revenue (penerimaan) dan pengeluaran perusahaan yang tercermin dalam neraca laba-rugi perusahaan.

Ketiga Accounting exposure

Resiko Perubahan kurs valas terhadap neraca konsilidasi perusahaan. Misal profitabilitas perusahaan perusahaan akan lebih banyak jika terjadi apresiasi mata uang domestik karena perusahaan membayar impor yang semakin menurun. 
Resiko investor asing terhadap perubahan kurs valas harus di antisipasi oleh pemodal tersebut. Seperti merosotnya nilai mata uang domestik akan menyebabkan tingkat rate of return yang diperoleh pemodal asing dari membeli dan menjual saham domestik akan menurun. Ini terjadi karena jika di kembalikan ke denominasi mata uang investor maka akan cenderung lebih kurang bernilai.

Permasalahan investasi baik menentukan jumlah maupun kesempatan untuk melakukan investasi, keynes mendasarkan teorinya atas konsep Marginal Efficiency of Invesment (MEI), yaitu bahwa investasi itu akan dijalankan oleh seorang pengusaha bilamana MEI masih lebih tinggi dari pada tingkat bunga. Jelasnya investasi ditentukan oleh faktor-faktor lain diluar interest rate. Dilihat dari model kurvanya, menunjukkan hubungan antara nilai investasi yang terjadi dengan tingkat bunga dan perubahan tingkat bunga diikuti dengan perubahan harga barang modal.

Menurut Nopirin (1987:25), inflasi adalah proses kenaikan harga-harga umum barang-barang secara terusmenerus.

Laju inflasi merupakan tingkat perubahan harga secara umum unutk berbagai jenis produk dalam rentang waktu tertentu.

Ketika biaya produksi naik akibat inflasi, hal ini akan sangat merugikan pengusaha dan ini menyebabkan kegiatan investasi beralih pada kegiatan yang kurang mendorong produk nasional, seperti tindakan para spekulan yang ingin mencari keuntungan sesaat.

Pada saat kondisi harga tidak menentu (inflasi) para pemilik modal cenderung menanam modalnya dalam bentuk pembelian tanah, rumah, bangunan. Pengalihan investasi seperti ini akan menyebabkan investasi produktif berkurang dan kegiatan ekonomi menurun.

Inflasi menimbulkan efek yang buruk pada perdagangan dan mematikan pengusaha dalam negeri. Hal ini dikarenakan kenaikan harga menyebabkan produk-produk dalam negeri tidak mampu bersaing dengan produk negeri lain.

Inflasi menimbulkan dampak yang buruk pula pada neraca pembayaran. Karena menurunnya ekpor dan meningkatnya impor menyebabkan ketidakseimbangan terhadap aliran dana yang masuk dan keluar negeri.

Menurut Yuki (www.kompas.com, 25 Nopember 2008) Secara teoritis, investasi pada saham dapat memberikan perlindungan nilai (hedge) yang baik dari pengaruh inflasi karena saham merupakan klaim terhadap aset-aset riil. Teori in dikemukakan oleh Bodie dalam common stocks as a hedge againts inflation, journal of finance, 1976. Berdasarkan teori tersebut, tingkat pengembalian riil dari saham seharusnya tidak terpengaruh oleh perubahan hargaharga barang dan jasa. Berlawanan dengan harapan teori tersebut, kenyataan di Amerika Serikat menunjukkan bahwa inflasi dan tingkat pengembalian investasi pada saham berkorelasi secara negatif dalam arti bahwa inflasi ynag tinggi cenderung disertai dengan tingkat pengembalian investasi pada saham yang rendah.

Di sisi lain, studi yang dilakukan oleh Spyrou, Are Stocks a good hedge againts inflation, evidence from emerging market, 2004 menyimpulkan bahwa di beberapa negara berkembang, kenyataan empiris menunjukkan bahwa pada beberapa emerging stocks markets inflasi berkorelasi secara positif dengan tingkat pengembalian saham. Dan Indonesia sebagai salah satu negara dalam kelompok emerging countries mengindikasikan bahwa pola kinerja 
bursa saham Indonesia mirip dengan pola kinerja bursa saham Amerika Serikat dimana kinerja positif dari investasi pada saham didorong oleh tingkat inflasi yang terkendali dan meningkatnya aktivitas ekonomi riil. Jadi dapat disimpulkan apabila inflasi naik maka indeks harga saham akan turun.

Hal ini disebabkan karena inflasi akan menyebabkan daya beli masyarakat akan turun, sehingga berimbas pada penjualan perusahaan dan sebagainya. Pada dasarnya tujuan investasi adalah mendapatkan tingkat pengembalian (rate of return) yang tinggi padahal ketika terjadi inflasi daya beli lemah ketika pendapatan tetap, maka perusahaan akan rugi yang akan tercermin pada harga saham gabungan.

\section{METODE PENELITIAN}

Untuk mencapai tujuan penelitian akan digunakan analisi regresi linear berganda terhadap model yang digunakan. Masing-masing regresi akan dilakukan uji diagnostic yang meliputi pengujian statistik baik secara individual (t-test) maupun secara serentak (F test) atas nilai periksa. Disisi lain untuk pemenuhan prediksi yang valid harus terpenuhinya sejumlah asumsi klasik diantaranya normalitas, heteroskedastisitas, multikolinearitas, dan autokorelasi. Untuk itu dilakukan pula pengujian uji ekonometrika terhadap model yang digunakan (Gujarati, 1999).

Variabel-variabel suku bunga luar negeri (suku bunga the fed) diwakili dengan $X_{1}$, kurs Rupiah/US\$ diwakili dengan $\mathrm{X}_{2}$, inflasi diwakili dengan $\mathrm{X}_{3}$ dan indeks harga saham gabungan diwakili oleh Y. sedangkan variabel lain yang tidak terangkum dimasukkan dalam error term (e), sehingga secara sederhana dapat dinyatakan sebagai berikut:
$\mathrm{Y}=\mathrm{f}\left(\mathrm{X}_{1}, \mathrm{X}_{2}, \mathrm{X}_{3}, \mathrm{e}\right)$

Dengan variabel $Y$ sebagai variabel dependent (terikat) dan variabel $\mathrm{X}_{1}, \mathrm{X}_{2}, \mathrm{X}_{3}$ sebagai variabel independent (bebas), maka sesuai alat analisa ordinary least square, untuk melihat pengaruh variabel bebas terhadap variabel terikat maka persamaan diatas ditransformasikan dalam bentuk OLS (Gujarati, 1999) sebagai berikut :

$\mathrm{Y}=\mathrm{a}+\mathrm{b}_{1} \mathrm{X}_{1}+\mathrm{b}_{2} \mathrm{X}_{2}+\mathrm{b}_{3} \mathrm{X}_{3}+\mathrm{e}$

Dimana :

Y : Indeks Harga Saham Gabungan (IHSG); $\mathrm{X}_{1}$ : Suku Bunga Luar Negeri (The Fed); $\mathrm{X}_{2}$ : Kurs Rupiah/US\$; $\mathrm{X}_{3}$ : Inflasi; e: Variabel pengganggu; a: Intersep; $b_{1}, b_{2}$ : koefisien regresi.

Untuk menguji kuat tidaknya pengaruh masing-masing variabel bebas dan variabel terikat perlu dilakukan tes dengan rumus berikut:

$\mathrm{T}_{\text {hitung }}=\frac{b-\beta}{s_{e}(\beta)}$

Keterangan:

$\mathrm{T}_{\text {hitung }}$ : besar hitung

b : regresi/koefisien ke 1

$\beta \quad$ : rata-rata koefisien regresi

se $\quad$ standar eror

Uji $\mathrm{t}$ merupakan uji signifikasi terhadap masing-masing koefisien regresi secara parsial yaitu untuk melihat pengaruh dari variabel bebas secara parsial terhadap variabel terikat, dimana hipotesa yang digunakan sebagai berikut:

Ho $=\beta \mathrm{i}=0$

Artinya variabel indikator ekonomi yang terdiri dari suku bunga The Fed, nilai tukar Rp/US\$ serta tingkat inflasi secara parsial tidak berpengaruh signifikan terhadap Indeks Harga Saham Gabungan.

$\mathrm{Hi}=\beta \mathrm{i} \neq 0$

Artinya variabel indikator ekonomi yang tediri dari suku bunga The Fed, nilai tukar Rp/US\$ serta tingkat inflasi secara parsial berpengaruh signifikan 
terhadap Indeks Harga Saham Gabungan.

Jika nilai $\mathrm{t}$ hitung $<\mathrm{t}$ tabel dan nilai koefisien signifikan (nilai probabilitas) : taraf signifikan yang ditetapkan $(\alpha=5 \%)$, maka Ho diterima atau ditolak Ha, berarti suku bunga The Fed, nilai tukar Rp/US\$ serta tingkat inflasi secara parsial tidak berpengaruh terhadap Indeks Harga Saham Gabungan.

Jika nilai $\mathrm{t}$ hitung $>\mathrm{t}$ tabel dan nilai koefisien signifikan (nilai probabilitas) : taraf signifikan yang ditetapkan $(\alpha=5 \%)$, maka Ho ditolak atau menerima $\mathrm{Ha}$, berarti suku bunga The Fed, nilai tukar Rp/US\$ serta tingkat inflasi secara parsial berpengaruh terhadap Indeks Harga Saham Gabungan.

Untuk mengetahui hubungan secara serentak antara variabel bebas terhadap variabel terikat dengan menggunakan uji $\mathrm{f}$ tes dengan rumus:

$F=\frac{\mathrm{R}^{2} /(\mathrm{k}-1)}{\left(1-\mathrm{R}^{2}\right) /(\mathrm{N}-\mathrm{k})}$

\section{Dimana :}

$\mathrm{R}^{2} \quad$ : koefisien determinasi

$\mathrm{K}$ : jumlah variabel independent

$\mathrm{N} \quad$ : jumlah sampel

Uji $F$ merupakan uji signifikan terhadap keseluruhan koefisien regresi secara simultan, yaitu untuk melihat pengaruh yang signifikan dari seluruh variabel bebas terhadap variabel terikat. Hipotesis yang digunakan sebagai berikut:

Ho $=\beta_{1}=\beta_{2}=\beta_{3}=0$

Artinya variabel indikator makro ekonomi yang terdiri dari suku bunga The Fed, nilai tukar Rp/US\$ serta tingkat inflasi secara serentak tidak berpengaruh signifikan terhadap Indeks Harga Saham Gabungan.

$\mathrm{Ha}=\beta_{1} \neq \beta_{2} \neq \beta_{3} \neq 0$
Artinya variabel indikator makro ekonomi yang terdiri dari suku bunga The Fed, nilai tukar Rp/US\$ serta tingkat inflasi secara serentak berpengaruh signifikan terhadap Indeks Harga Saham Gabungan.

Dasar pengambilan keputusan untuk pengujian hipotesis yang diajukan adalah sebagai berikut

Jika $\mathrm{F}$ hitung $<\mathrm{F}$ tabel dan nilai koefisien signifikan (nilai probabilitas) : taraf signifikan yang ditetapkan $(\alpha=$ $5 \%$ ), maka Ho diterima atau ditolak Ha, berarti suku bunga The Fed, nilai tukar Rp/US\$ serta tingkat inflasi secara serentak tidak berpengaruh terhadap Indeks Harga Saham Gabungan.

Jika nilai $\mathrm{F}$ hitung $>\mathrm{F}$ tabel dan nilai koefisien signifikan (nilai probabilitas) : taraf signifikan yang ditetapkan $(\alpha=5 \%)$, maka Ho ditolak atau menerima $\mathrm{Ha}$, berarti suku bunga The Fed, nilai tukar Rp/US\$ serta tingkat inflasi secara serentak berpengaruh terhadap Indeks Harga Saham Gabungan.

\section{PEMBAHASAN}

Suku bunga The Fed merupakan suku bunga yang banyak digunakan oleh investor untuk pertimbangan sebelum menempatkan dananya atau melakukan investasi di bursa saham. Adapun perkembangan tingkat suku bunga The Fed bulan Januari 2006 sampai dengan bulan Juli tahun 2008 dapat dilihat pada gambar dibawah ini

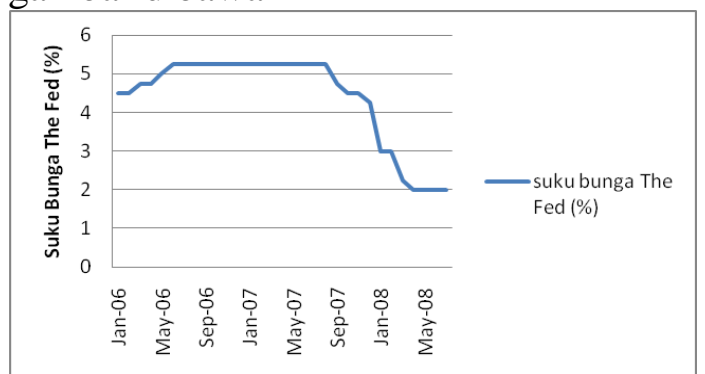

Gambar 2. Suku Bunga The Fed Periode Januari 2006-Juli 2008

Sumber: www.federalreserve.gov, 2008 
Berdasarkan gambar diatas diketahui bahwa pada bulan Januari sampai Juni tahun 2006 tingkat suku bunga The Fed mengalami kenaikan terus menerus. Seperti diketahui pada 26 September 2006 Federal Reserve menaikkan suku bunga The Fed untuk ke 17 kalinya sejak pertengahan tahun 2004 lalu. Suku bunga The Fed naik sebesar 25 basis poin sehingga menjadi 5.25\%. Sedangkan pada bulan September 2007 suku bunga The Fed mengalami penurunan 50 basis poin menjadi $4.75 \%$ akibat bergejolaknya perekonomian Amerika, yang muncul setelah kembalinya kekuatiran akan sektor ketenagakerjaan, terpuruknya laporan perumahan, dan faktor ketidakpastian akibat adanya krisis kredit sampai juli 2008 menjadi $2.00 \%$.

Pengaruh perkembangan nilai tukar dapat mendorong investor untuk melakukan investasi di bursa saham. Karena perubahan nilai tukar akan memengaruhi perkembangan ekspor impor dan tentunya akan mempengaruhi kinerja perusahaan. Jika kinerja perusahaan semakin baik, maka harga saham akan semakin mahal. Untuk lebih jelasnya melihat perkembangan nilai tukar Rp terhadap US\$ mulai Januari 2006 sampai dengan Juli 2008 dapat dilihat dibawah ini.

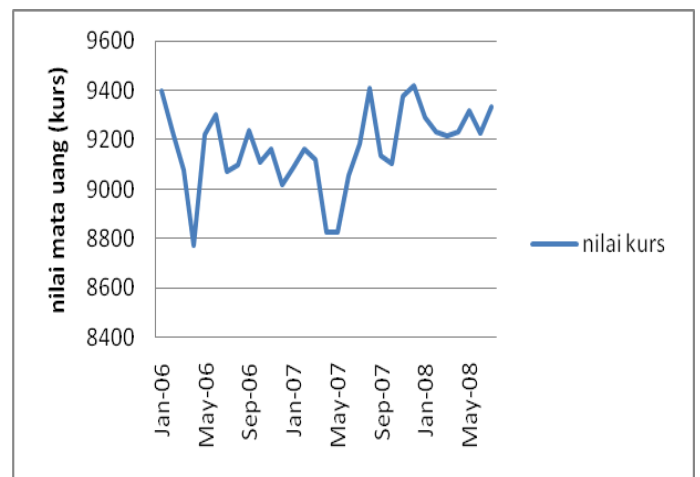

Gambar 3. Nilai tukar Rp/US\$ Periode Januari 2006-Juli 2008

Sumber: Depkeu, 2008
Berdasarkan gambar diatas dapat dilihat bahwa pada awal 2006 kurs berada di kisaran 9400 tetapi april 2006 mengalami penguatan yang cukup signifikan, ini karena kondisi fundamental perekonomian Indonesia yang dinilai semakin membaik dewasa ini menyebabkan derasnya aliran modal jangka pendek (hot money) yang masuk ke Indonesia. Sedangkan pada tahun 2008 kurs stabil.

Inflasi adalah kenaikan harga barang-barang yang menyebabkan daya beli masyarakat akan turun, sehingga berimbas pada penjualan perusahaan dan sebagainya. Dibawah ini merupakan perkembangan inflasi periode Januari 2006 - Juli 2008.

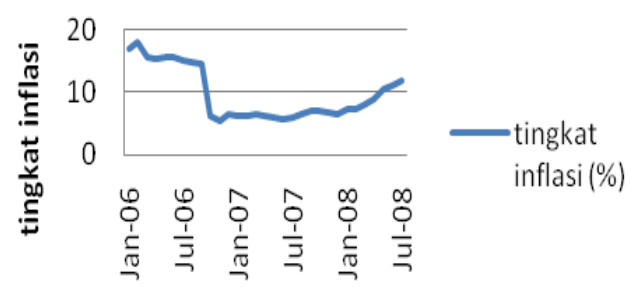

Gambar 4. Tingkat Inflasi di Indonesia Periode januari 2006-juli 2008

Sumber: Bank Indonesia, 2008

Berdasarkan gambar diatas bahwa pada sepanjang tahun 2006 inflasi mengalami penurunan hingga $6.60 \%$ akibat daya beli masyarakat masih lemah akibat kenaikan harga bahan bakar minyak di bulan Oktober 2005. Sedangkan pada tahun 2007 inflasi berada di kisaran dan 6.59 akhir Juli 2008 inflasi mengalami kenaikan hingga 11.90 akibat adanya tren kenaikan harga bahan makanan rata-rata sebesar 1,85\%.

Naik turunnya IHSG merupakan indikator naik turunnya harga saham di Bursa efek. Selain faktor fundamental seperti laporan keuangan perusahaan, faktor perkembangan ekonomimakro 
seperti inflasi, nilai tukar dan tingkat suku bunga. Ternyata pergerakan IHSG di bursa efek Indonesia juga dipengaruhi faktor lain seperti fluktuasi minyak dunia, adanya pengaruhi dari Luar Negeri dapat Dow Jones, Nikkei, Hangseng maupun stabilitas keamanan Dalam Negeri.

Pada tahun 2006 rata-rata pergerakan cukup stabil dan ada kecendrungan naik dimana nilai IHSG di Bursa menembus level 1500 poin. Untuk lebih jelasnya melihat perkembangan pergerakan nilai IHSG mulai Januari 2006-Juli 2008 dapat diihat dibawah ini

Berdasarkan tabel diatas bahwa sepanjang tahun 2007, kondisi pasar modal di BEI masih bullish. Dan beberapa data yang mendukung kinerja pasar modal antara lain jumlah emiten terus meningkat, kapitalisasi saham besar, Indeks Harga Saham Gabungan terus meningkat menyentuh level 2830.260 point.

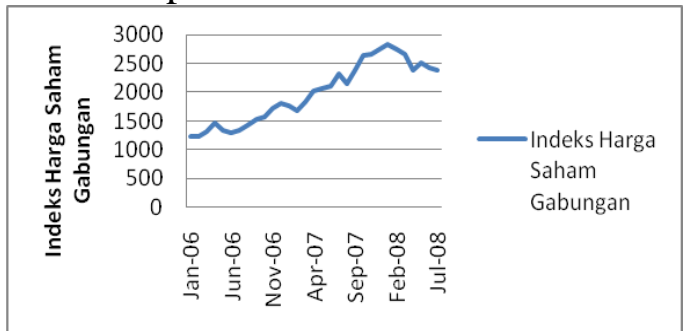

Gambar 5. Indeks Harga Saham

Gabungan Periode Januari 2006-Juli 2008

Sumber: Pojok BEI UMM, 2008

Berdasarkan gambar diatas dapat dilihat bahwa pada awal tahun 2008 nilai indeks mengalami kenaikan akibat keputusan bank sentral AS (The Federal Reserve) memangkas suku bunga 75 basis poin. Nilai indeks pada bulan Desember 2007 sebesar 2745.826 poin berubah menjadi 2830.260 poin Januari 2008.
Tabel 1. Hasil Uji Regresi

\begin{tabular}{|c|c|c|c|c|}
\hline \multicolumn{5}{|c|}{$\begin{array}{l}\text { Dependent Variable: Y } \\
\text { Method: Least Squares } \\
\text { Included observations: } 31\end{array}$} \\
\hline Variable & $\begin{array}{l}\text { Coefficie } \\
\text { nt }\end{array}$ & $\begin{array}{l}\text { Std. } \\
\text { Error }\end{array}$ & t-Statistic & Prob. \\
\hline $\mathrm{C}$ & 230.3077 & & 0.079534 & 0.9372 \\
\hline $\mathrm{X} 1$ & -252.4613 & $\begin{array}{l}2895.7 \\
41.963\end{array}$ & -6.016280 & 0.0000 \\
\hline $\mathrm{X} 2$ & 0.403862 & 0.3081 & 1.310670 & 0.2010 \\
\hline $\mathrm{X} 3$ & -85.06855 & 10.918 & -7.790880 & 0.0000 \\
\hline $\begin{array}{l}\text { R-squared } \\
\text { Adjusted } \\
\text { squared }\end{array}$ & $\begin{array}{l}0.797827 \\
0.775363\end{array}$ & $\begin{array}{l}\text { Mear } \\
\text { S.D. }\end{array}$ & $\begin{array}{l}\text { ependent var } \\
\text { pendent var }\end{array}$ & $\begin{array}{l}1988.9 \\
529.38\end{array}$ \\
\hline S.E. of regression & 250.9064 & Akai & info criterion & 14.007 \\
\hline $\begin{array}{l}\text { Sum squared } \\
\text { resid }\end{array}$ & 1699759. & Schy & criterion & 14.192 \\
\hline Log likelihood & -213.1232 & F-sta & & 35.516 \\
\hline $\begin{array}{l}\text { Durbin-Watson } \\
\text { stat }\end{array}$ & 0.653751 & Prob & statistic) & 0.000 \\
\hline
\end{tabular}

Dari hasil regresi diatas dapat disusun persamaan regresi sebagai berikut:

$\mathrm{Y}=230.3077-252.4613\left(X_{1}\right)+0.403862$ $\left(X_{2}\right)-85.06855\left(X_{3}\right)+$ ei

Model diatas dapat di interprestasikan sebagai berikut:

$$
\beta_{0}=-230.3077 ; \quad \text { nilai Indeks }
$$

Harga Saham Gabungan (Y) akan sebesar -230.3077 pada saat Suku Bunga The Fed $\left(\mathrm{X}_{1}\right)$, nilai tukar (X2) dan tingkat inflasi sama dengan nol.

$$
\beta_{1}=-252.4613 \text {; koefisien regresi }
$$
variabel suku bunga The Fed $\left(\mathrm{X}_{1}\right)$ akan sebesar -252.4613; berarti ada pengaruh negatif antara suku bunga The Fed terhadap Indeks harga Saham Gabungan. Jadi, apabila nilai suku bunga The Fed $\left(X_{1}\right)$ naik sebesar satu satuan, maka Indeks Harga Saham Gabungan (Y) akan turun sebesar -252.4613. Sebaliknya, apabila nilai suku bunga The Fed $\left(\mathrm{X}_{1}\right)$ turun sebesar satu satuan, maka Indeks harga Saham Gabungan akan naik sebesar -252.4613. Asumsi variabel yang lain tetap.

$$
\beta_{2}=0.403862 ; \text { koefisien regresi }
$$

variabel nilai tukar $\left(\mathrm{X}_{2}\right)$ sebesar 0.403862 . berarti ada pengaruh positif antara nilai tukar $\left(\mathrm{X}_{2}\right)$ terhadap Indeks 
harga Saham Gabungan sebesar 0.403862. Artinya apabila nilai tukar $\left(\mathrm{X}_{2}\right)$ naik sebesar satu satuan, maka Indeks Harga Saham Gabungan akan naik sebesar 0.403862 sebaliknya, apabila nilai tukar $\left(\mathrm{X}_{2}\right)$ turun sebesar satu satuan, maka Indeks Harga Saham Gabungan akan turun sebesar 0.403862 . Asumsi variabel yang lain tetap.

$\beta_{3}=-85.06855$; koefisien regresi variabel inflasi $\left(\mathrm{X}_{3}\right)$ sebesar -85.06855; berarti ada pengaruh negatif antara tingkat inflasi $\left(\mathrm{X}_{3}\right)$ terhadap Indeks harga Saham Gabungan. Apabila tingkat inflasi $\left(\mathrm{X}_{3}\right)$ naik sebesar satu satuan, maka Indeks Harga Saham Gabungan akan turun sebesar $\mathbf{- 8 5 . 0 6 8 5 5}$ sebaliknya, apabila tingkat inflasi $\left(\mathrm{X}_{3}\right)$ turun sebesar satu satuan, maka Indeks Harga Saham Gabungan akan naik sebesar -85.06855. Asumsi variabel yang lain tetap.

Untuk mengetahui pengaruh masing-masing variabel bebas maka digunakan uji t.

Hasil t ${ }^{\text {hitung }}$ dari variabel $\mathrm{X}_{1}$ adalah sebesar -6.016280 dari $\mathrm{t}$ tabel dengan tingkat signifikan $\alpha=5 \%$ dan derajat kebebasannya (df) 28 diperoleh $t_{\text {tabel }}$ sebesar 2,048, maka $t_{\text {hitung }}>\mathrm{t}_{\text {tabel }}$. Hal ini menunjukkan bahwa variabel tingkat suku bunga The Fed berpengaruh signifikan negatif terhadap Indeks Harga Saham Gabungan (Y), artinya apabila suku bunga The Fed meningkat maka Indeks Harga Saham Gabungan akan menurun, dan sebaliknya apabila suku bunga The Fed menurun maka Indeks Harga Saham Gabungan akan meningkat.

Hasil t ${ }^{\text {hitung }}$ dari variabel $\mathrm{X}_{2}$ adalah sebesar 1,310670 dari $\mathrm{t}$ tabel dengan tingkat signifikan $\alpha=5 \%$ dan derajat kebebasannya (df) 28 diperoleh $\mathrm{t}$ tabel sebesar 2,048, maka $\mathrm{t}_{\text {hitung }}<\mathrm{t}_{\text {tabel }}$. Hal ini menunjukkan Ho yang menyatakan tidak ada pengaruh antara variabel nilai tukar terhadap Indeks Harga Saham Gabungan diterima dan menolak Ha. Kesimpulannya, bahwa pengaruh secara parsial antara variabel nilai tukar terhadap Indeks Harga Saham Gabungan adalah tidak signifikan.

Hasil t ${ }^{\text {hitung }}$ dari variabel $\mathrm{X}_{3}$ adalah sebesar -7,790880, dari t tabel dengan tingkat signifikan $\alpha=5 \%$ dan derajat kebebasannya (df) 28 diperoleh $\mathrm{t}$ tabel sebesar 2,048, maka $\mathrm{t}_{\text {hitung }}>\mathrm{t}_{\text {tabel }}$. Hal ini menunjukkan bahwa variabel inflasi berpengaruh signifikan negatif terhadap Indeks Harga Saham Gabungan (Y), artinya apabila inflasi meningkat maka Indeks Harga Saham Gabungan akan menurun dan sebaliknya apabila inflasi menurun maka Indeks Harga Saham gabungan meningkat.

Nilai F statistik dapat dilihat pada hasil regresi yaitu sebesar 35,51624, sedangkan dengan tingkat signifikan $\alpha=5 \%$ diperoleh $\mathrm{F}^{\text {table }}$ sebesar 2,95. Karena $F$ hitung $>F$ tabel $(35,51624>2,95)$, maka Ho ditolak, artinya suku bunga The Fed (\%), nilai tukar (Rp/US\$) dan inflasi (\%) secara bersama-sama berpengaruh signifikan terhadap indeks harga saham gabungan.

Koefisien determinasi $\left(\mathrm{R}^{2}\right)$ digunakan untuk mengetahui kesesuaian atau ketepatan hubungan antara variabel bebas (X) dengan variabel terikat (Y) dalam suatu persamaan regresi. Semakin besar nilai koefisien determinasi semakin baik kemampuan variabel bebas (X) menjelaskan variabel terikat(Y).

Berdasarkan regresi diatas diperoleh nilai $\mathrm{R}^{2}$ sebesar 0.797827 $(79,78 \%)$. Berarti kemampuan model yaitu variabel suku bunga The Fed $\left(\mathrm{X}_{1}\right)$, nilai tukar $\left(\mathrm{X}_{2}\right)$ dan inflasi $\left(\mathrm{X}_{3}\right)$ dalam menjelaskan variabel indeks harga saham gabungan (Y) sebesar 79,78\%. Sedangkan sisanya sebesar 0,202173 $(20,22 \%)$ dijelaskan oleh variabel lain diluar model (variabel 
pengganggu/standar error). Berdasarkan nilai Fhitung > Ftabel $(35,51624>2,95)$ ini berarti koefsien determinasi R2 sebesar 0.797827 adalah signifikan dan begitu juga dilihat dari $\mathrm{F}$ probabilitas $(\mathrm{F}$ siginifikan) 0.0000 adalah signifikan.

Dari analisa data yang dilakukan menunjukkan bahwa tidak sepenuhnya variabel-variabel diatas menunjukkan pengaruh terhadap harga saham pertambangan. Sentimen pasar yang menimbulkan kekhawatiran pelaku pasar juga sangatlah mungkin mempengaruhi harga saham.

Secara toritis suku bunga The Fed mempunyai pengaruh negatif terhadap Indek Harga Saham Gabungan, berarti ketika The Fed meningkatkan suku bunga maka banyak uang yang terserap di Amerika, hal tersebut berakibat investasi di tabungan lebih menarik daripada investasi di saham.

Di Indonesia, ketika The Fed meningkatkan suku bunga maka SBI naik kemudian suku bunga bank atau tabungan naik akibatnya dana terserap ke perbankan, investasi di tabungan menjadi lebih menarik daripada investasi disaham sehingga Indeks Harga Saham Gabungan turun.

Dari hasil penelitian ini tercermin pula keadaan yang terjadi, ini terlihat nilai koefisien regresi sebesar -273.6319. Variabel suku bunga The Fed ini berpengaruh negatif terhadap Indeks Harga Saham Gabungan, sehingga hal tersebut sesuai dengan hipotesis bahwa apabila suku bunga The Fed naik akan terjadi dana keluar (capital out flow) maka akan semakin banyak investor yang menjual sahamnya dan beralih ke tabungan yang ada di luar negeri (Amerika) dan Indeks Harga Saham Gabungan turun. Sebaliknya apabila suku bunga The Fed turun akan terjadi dana masuk (capital inflow) maka akan semakin banyak investor luar negeri membeli saham di Indonesia sehingga Indeks Harga Saham Gabungan naik. 4.6.2 Variabel Inflasi

Secara teoritis inflasi mempunyai pengaruh negatif terhadap Indeks Harga Saham Gabungan, berarti ketika inflasi naik maka Indeks Harga Saham Gabungan turun. Hal ini karena harga faktor-faktor produksi naik, sedangkan daya beli lemah ketika pendapatan tetap, maka perusahaan akan rugi yang akan tercermin pada Indeks Harga Saham Gabungan.

Dari hasil penelitian ini tercermin pula keadaan yang terjadi, ini terlihat nilai koefisin regresi sebesar -83.89346 . Variabel inflasi ini berpengaruh negatif terhadap Indeks Harga Saham Gabungan, sehingga hal tersebut sesuai dengan hipotesis bahwa apabila inflasi naik maka investasi di sektor riil lebih menarik daripada investasi di pasar modal. Sebaliknya apabila inflasi turun maka investasi di pasar modal lebih menarik daripada investasi disektor riil.

Dari hasil penelitian diatas terlihat bahwa nilai koefisien regresi variabel suku bunga The Fed $=-273.6319$, inflasi $=-83.89346$. Dengan demikian variabel suku bunga The Fed mempunyai pengaruh yang sangat dominan tehadap Indek Harga Saham Gabungan karena nilai koefisien sebesar -273.6319 lebih kecil dari tingkat signifikan 5\%.

\section{PENUTUP}

Variabel Independen $\left(\mathrm{X}_{1}\right)$ atau suku bunga The Fed mencapai koefisien -273.6319 yang berarti jika terjadi perubahan kenaikan satu poin suku bunga The Fed maka akan menurunkan Indeks Harga Saham Gabungan 273.6319.

Variabel independen $\left(\mathrm{X}_{3}\right)$ arau tingkat inflasi mencapai koefisien regresi -85.06855 yang berarti jika terjadi perubahan kenaikan satu poin tingkat 
inflasi maka akan menurunkan Indeks Harga Saham Gabungan -85.06855.

Variabel Dependen (Y) atau Indeks Harga Saham Gabungan di Indonesia Stock Excange akan sebesar 0.784963 jika pada saat itu suku bunga The Fed $\left(\mathrm{X}_{1}\right)$ dan tingkat inflasi $\left(\mathrm{X}_{3}\right)$, sama dengan nol (konstan).

Pengaruh secara parsial antara variabel suku bunga The Fed, variabel tingkat inflasi terhadap Indeks Harga Saham Gabungan adalah signifikan, tapi variabel tingkat suku bunga The Fed berpengaruh lebih dominan terhadap Indeks Harga Saham Gabungan.

\section{DAFTAR PUSTAKA}

Asfia Murni, 2006. Ekonomika Makro, Refika Aditama, Bandung.

Boediono, 2007. IHSG dan Rupiah Menguat, Pasar Merespon Kebijakan The Fed, 2007. (www.skmindosat.aceboard.com. Diakses tanggal 5 Agustus 2007)

Damodar Gujarati, 1999. Ekonometrika Dasar, Terjemahan Sumarno, Erlangga, Jakarta.

Farial Anwar, 2008. The Fed Tentukan Arah Perekonomian Global. (www.inilah.com diakses tanggal 6 Agustus 2008)

Mandala, 2004. Uang, Perbankan dan Ekonomi Moneter, Fakultas Ekonomi Universitas Indonesia, Jakarta.

Mankiw N. Gregory, 2002. Principle Of Economics, $3^{\text {th }}$ edition, terjemahan Chriswan Sungkono, Salemba Empat, Jakarta.
Rusdin, 2006. Pasar Modal, Alfabeta, Bandung.

Sigit Wibowo, 2008. The Fed Diperkirakan Turunkan Suku Bunga 25 Bps Indeks BEI masih Fluktuatif.(www.sinarharapan.com diakses tanggal 6 agustus 2008)

Tatang Cahyono, 2008. Fluktuasi Nilai Tukar Rupiah dan Tingkat Suku Bunga Terhadap IHSG di BEJ, Skripsi, Program Studi Ilmu Ekonomi Pembangunan, Fakultas Ekonomi, UMM, Malang.

Tjiptono Darmadi, 2001. Pasar Modal Di Indonesia, Salemba Empat, Jakarta.

Yuki Indrayadi, Inflasi dan Kaitannya Dengan IHSG (www.kompas.com diakses tanggal 25 Nopember 2008) 